\title{
Emptying the Sea with a Spoon? \\ Non-governmental Providers of Migrants' Search and Rescue in the Mediterranean ${ }^{1}$
}

\author{
Eugenio Cusumano
}

\begin{abstract}
In 2015 and 2016, 1,200,000 migrants crossed the Mediterranean into Europe. At least 6,000 went missing at sea. In response to states' failure to provide adequate search and rescue (SAR) services, several non-governmental organisations (NGOs) have launched their own SAR operations. The Migrants Offshore Aid Station (MOAS), Medicins Sans Frontieres, SOSMediterranee, Sea-Watch, Sea-Eye, and Pro-Activa Open Arms all deployed boats in the Central Mediterranean and Aegean.

This article provides the first empirical analysis of SAR NGOs, outlining their structure and operating models, investigating the reasons underlying their proliferation and assessing their contribution to mitigating the loss of life at sea.
\end{abstract}

Keywords: Search and Rescue, NGOs, migrations, MOAS, Medicins Sans Frontieres

\footnotetext{
${ }^{1}$ This is a pre-reviewed and slightly amended version of the article published on Marine Policy 76 (2018)
} 


\section{Introduction}

In 2015 only, over 1 million migrants crossed the Mediterranean into Europe, roughly five times more than the year before. The death toll, amounting to 3,771 officially recorded casualties, was dramatic. Migrant crossings in the first half of 2016 were only slightly inferior. At the end of June 2016, there had been 222,291 arrivals by sea, with at least 2,888 declared dead or missing (IOM 2016).

The humanitarian crisis in the Central Mediterranean peaked after October 2014, when the Italian government suspended its Search and Rescue (SAR) operation Mare Nostrum, replaced by replaced by Frontex operation Triton. Narrowly focused on border control, Triton proved illequipped to counter the humanitarian emergency (Carrera and Den Hartog 2015, Patalano 2015). Different aid organisations have attempted to fill the gap created by the lack of proactive SAR operations. In the summer of 2014, the philanthropists Christopher and Regina Catrambone set up the Migrant Offshore Aid Station (MOAS), reconverting a fishing boat into a SAR vessel equipped with drones and manned with former Maltese military personnel and medical staff initially provided by the Amsterdam branch of Médecins sans Frontières (MSF). MOAS' operations offered an example that has increasingly been replicated by other organisations. The operational branches of MSF headquartered in Barcelona and Brussels developed their independent SAR capabilities by using own ships, the Bourbon Argos and Dignity I. In February 2016, SOS Méditerranée started SAR operations from a chartered 77-metre ship, the Aquarius, capable of operating under all weather conditions and hosting up to 500 people on board. Two German NGOs, Sea-Watch and Sea-Eye, have relied on smaller reconverted fishing vessels to actively search for boats in distress, providing support to migrants whilst awaiting the arrival of a larger ship. The Spanish organisation Pro-Activa, initially operating solely in the Aegean by means of Rigid Hull Inflatable Boats (RHIBs), started operations in the Central Mediterranean too by relying on a sailing boat.

NGOs have provided a crucial contribution to the mitigation of the loss of life at sea. The existing literature, however, has only briefly touched upon the existence and proliferation of SAR NGOs (Perkowsky 2016). This research relies on semi-structured interviews with personnel from SAR NGOs, Italian Coast Guard and Navy personnel and one Greek Coast Guard officer, as well as the direct observation of one consultation workshop involving both military personnel and NGOs organised by Italian navy and one meeting involving representatives from all SAR NGOs in April 2016. By relying on this body of information, this article provides the first empirical analysis of the non-governmental provision of SAR, conducting a structured, focused comparison (George and Bennett 2005: 67-73) of all the NGOs who have engaged in these types of operations up to June 2016. By doing so, the paper outlines the structure and operating models of each of these organisations, investigating the reasons underlying their rapid proliferation and assessing the extent to which they have contributed to the mitigation of loss of life at sea.

To this end, the article is divided as follows. The first section provides a short overview of the unfolding of the migrations crisis from operation Mare Nostrum until the end of June 2016. The second section conducts a comparative analysis of all the NGOs involved in Search and Rescue. The third section identifies the key factors underlying the proliferation of SAR NGOs over the last three years. The conclusions conduct a preliminary assessment of the impact of nongovernmental SAR and outline some avenues for future research. 


\section{The Mediterranean Migrations Crisis: An Overview}

Migrations across the Mediterranean are far from novel. The movement of people from North Africa towards the Southern coast of Italy intensified in the 2000s and peaked in the wake of the Arab Spring due to the large number of refugees created by the civil war in Syria and the disintegration of Libya, which made its ports an ideal safe haven for smugglers. In the second half of 2015, most asylum seekers from the Middle East reoriented towards the Eastern Mediterranean route, attempting to reach Northern Europe by crossing the Aegean Sea from the Western coast of Turkey into Greece (IOM 2016, Council of the EU 2016). This, however, did not substantially decrease the number of migrants following the Central Mediterranean route. By capitalising on the higher fees paid by Syrians and exploiting Libya's state failure, smugglers consolidated their business by offering lower tariffs to migrants from Sub-Saharan Africa, whose numbers also increased (Toaldo 2015).

The Italian government started conducting SAR operations to counter the loss of life at sea as early as 2004 through operation Constant Vigilance. Between 2011 and 2013, the Italian Navy conducted 139 rescue missions, reportedly saving more than 16,000 people (Patalano 2015). In October 2013, the sinking of a large boat caused the death of over 350 migrants. Calls for action by the Pope and Italian public opinion urged Italian decision-makers to undertake more proactive SAR activities by launching operation Mare Nostrum, which lasted from 18 October 2013 to 31 October 2014. The Navy deployed 34 warships on a rotation basis, rescuing over 156,000 migrants (Patalano 2015). In late 2013, however, Italian frustration with the lack of European border sharing and other states' criticism that the operation was a 'pull factor' of migrations led to the replacement of operation Mare Nostrum with the Frontex operation Triton in late 2014 (Travis 2014). Unlike its predecessor, Triton was not a SAR operation, but a mission primarily focused on border control (Carrera and Den Hartog 2015: 7-10; Llewellyn 2015: 1012). Triton only operated within 30 miles from the Italian coast, comprised a much smaller number of assets, and was run on a third of Mare Nostrum's budget (Patalano 2015:17). Consequently, the humanitarian emergency intensified. Civil society forcefully criticized the decision to suspend Mare Nostrum, arguing that 'Because they decided to retreat their state-led SAR assets in all knowledge of the deadly consequences this would have, EU policy makers and agencies carry a strong degree of responsibility for these deaths' (Heller, Pezzani et al. 2015: 7; Amnesty International 2015). In the summer of 2015, the European Council decided to complement the patrolling of its external border with the Common Security and Defence Policy (CSDP) operation EUNAVFOR Med 'Sophia', aimed at countering illegal migrations by seizing and destroying smugglers' boats (Tardy 2015, Llewellyn 2015). The Italian Navy also kept a smaller presence in the Central Mediterranean through operation Mare Sicuro (Safe Sea), aimed at securing humanitarian and commercial activities in the area (Ministero della Difesa 2015). Other European Union member states, such as the UK and Ireland, contributed to SAR on a voluntary basis with some of their Navy and Coast Guard assets (Pollack 2016).

By late 2015, the worsening weather conditions reduced the number of migrants crossing the Central Mediterranean. The number of migrants reaching Greece through the Aegean Sea, by contrast, increased dramatically. Although narrower, the Aegean Sea was also treacherous. New widely publicized tragedies shifted attention towards the Eastern Mediterranean, where the financial crisis and the distrust between the Turkish and the Greek governments in the contested waters of the Aegean complicated the launching of effective SAR operations. The increase in migratory flows through the Aegean led to the deployment of Frontex operation Poseidon, 
primarily focused on border control like its Central Mediterranean counterpart Triton (Llewellyn 2015). In February 2016, NATO also deployed its Maritime Group in the region (Chryssogelos 2016). To ensure a more proactive effort to halt migrations from Turkish authorities, the EU recently agreed a EUR 6 billion aid package to Turkey (Council of the European Union 2016b). This agreement seems to have drastically reduced the flow of migrants crossing the Aegean (IOM 2016). The number of migrants crossing the Central Mediterranean, however, remained substantially unchanged. Between January and June 2016, Italy witnessed 62,750 arrivals by sea compared to the 70,350 of the previous year. Smugglers' use of increasingly overloaded unseaworthy vessels and the increasing departure of migrant boats from Egypt has further enlarged the scope of the emergency, creating new challenges to the provision of effective SAR (Zandonini 2016).

Due to the present prominence and greater complexity of the humanitarian emergency in the Central Mediterranean, this article primarily focuses on non-governmental SAR operations conducted in the area between Libya, Malta, and Italy. NGO SAR operations in the Aegean, however, will also be briefly examined.

\section{The Rise of Private Providers of SAR}

Both international and local NGOs have played a key role in mitigating the humanitarian emergencies arising from mass migrations, conducting research, advocacy, and several support services for migrants on land, ranging from advocacy to legal support for visa applications and language and professional training (European Parliament 2016).

The direct involvement of NGOs in the provision of maritime SAR, however, is a much more recent phenomenon. The German NGO Cap Anamur helped saving Vietnamese boat people starting from 1979 already (Coppens and Somens 2010). It also operated in the Mediterranean, but suspended its activities in 2004 after some of its personnel faced prosecution in Italy for abetting illegal immigration (Basaran 2015: 211; Cuttitta 2014: 22-3). It was only in 2014 that non-governmental SAR operations restarted with the creation of MOAS. The ensuing subsections briefly examine each of the NGOs presently involved in SAR.

\subsection{The Migrant Offshore Assistance Station (MOAS)}

MOAS was created thanks to the initiative of Christopher and Regina Catrambone, who reportedly developed the idea of creating SAR NGO after seeing the floating coat of a shipwreck victim while on vacation in Sicily. They already had experience in the field of crisis management as the owners of Tangiers Group, a firm providing insurance investigations, evacuation, and intelligence for businesses operating in dangerous environments. Part of Tangiers' revenues were used to purchase a 40-metre Canadian fishing boat, the Phoenix, and convert it into a SAR vessel for a total cost of around 4 million EUR (Tremlett 2015). The ship was subsequently chartered for free to MOAS, established in 2014 as a Malta-based non-for-profit organisation.

The Phoenix was equipped with two rigid hull inflatable boats and two remotely piloted Camcopter S-100s, leased to MOAS at a subsidized rate. The drone producer, Schiebel, found in MOAS's activities an important form of advertisement, stressing that its Camcopters 'assisted in the rescue of over 8,800 refugees', helping MOAS 'become the first civilian organisation to use these high-tech helicopters for a great humanitarian purpose' (Schiebel 2015). The Phoenix has 
operated with 11 own personnel on board. The crew, consisting of personnel with a background in the Maltese Coast Guard and Navy, was led by captain Martin Xuereb, former Commander of the Armed Forces of Malta. During the first year of activities, MOAS operated in partnership with MSF Amsterdam, which provided six doctors and paramedics to be deployed on board free of charge. Eventually, however, MOAS decided to rely on the Italian Red Cross to provide medical support on board the Phoenix. In autumn 2015, MOAS extended its operations into the Aegean Sea by leasing a second vessel, the Responder, equipped with two high-speed rescue boats named after the two drowned Syrian children Aylan and Galip. The personnel on board comprise the chartered captain and crew, MOAS SAR personnel, and one doctor and one paramedic from the medical NGO Emergency. In the autumn of 2015, the Phoenix suspended its operations in the Central Mediterranean, where the humanitarian emergency was deemed less grave due to the worsening weather conditions and the larger number of vessels conducting SAR operations. In February 2016, the Phoenix was relocated to the Andaman Sea to counter the humanitarian emergency of migrations across the Bengal Gulf. Although the Phoenix still conducted SAR, its Southeast Asian operations were mainly based on intelligence and advocacy in partnership with two other NGOs, MigrantsReport.org and Fortify Rights. Drones were provided by the US defence firm Precision Integrated Programs (MOAS 2016a). Due to the renewed emergency in the Mediterranean, at the beginning of June 2016 MOAS restarted operations in the Central Mediterranean, deploying both the Phoenix and the Responder close to the Libyan shores.

In total, MOAS presently employs 35 personnel both on board and ashore, and its running costs currently amount to around EUR 400,000 per month. Funding consists entirely of private donations largely collected through crowd funding. In less than two years of activities, the NGO has conducted humanitarian support missions in three different theatres, reportedly contributing to saving over 13,000 migrants. MOAS's activities have obtained extensive coverage by international media, including Time, the Financial Times, and CNN, and received praise and awards by Italian authorities. The most important indicator of MOAS's success, however, lies in the emulation process that has taken place after its creation. MOAS's model, which has proven to be effective, financially viable, and supported by national governments and civil society alike, has inspired several other NGOs to started their own SAR operations.

\subsection{Médecins sans Frontières (MSF)}

Unlike MOAS, a small organisation established specifically for conducting maritime SAR, MSF is a large international medical NGO with offices in 28 countries and more than 30,000 personnel worldwide. Its activities are coordinated by six semi-independent operational centres (Fox 2014).

Although MSF has been involved in numerous humanitarian crises and often supported migrants on land, its involvement in maritime SAR is novel. Three different MSF operational branches have decided to become involved in SAR. MSF Amsterdam decided to circumvent its lack of maritime SAR by partnering with other organisations. It therefore reached an agreement with MOAS to provide medical personnel aboard the Phoenix. Once MOAS suspended operations in the Central Mediterranean, MSF Amsterdam started a partnership with another NGO, SOS-Mediterranee, providing six medical personnel aboard and covering part of the running costs.

Two other branches of MSF, on the other hand, decided to develop their independent 
SAR capabilities. Specifically, MSF Brussels charted a $68 \mathrm{mt}$ offshore supply vessel, the Bourbon Argos, from 9 May 2015. The Bourbon Argos has the capacity to carry up to 450 people to land. Its low deck and manoeuvrability makes it especially suitable for SAR operations. It operates with 29 people on board, 10 of which are MSF staff, including a SAR team, two interpreters and cultural mediators and MSF medical staff, who operate a fully-fledged hospital unit. The crew of the ship does not consist of MSF personnel, but of Eastern European professional sailors chartered together with the vessel.

One month after MSF Brussels deployed the Bourbon Argos on sea, MSF Barcelona decided to start its own operations by purchasing and reconverting a former fishing vessel, the $50 \mathrm{mt}$ Dignity I, which hosts a crew of 18 - all direct employees of MSF - and the capacity to carry up to 300 migrants. Purchasing and operating their own vessel required MSF Barcelona to create a ad hoc navigation company and directly hire a shipmaster, a chief engineer officer and other crew members. While more complex than the chartering of a boat, this solution was preferred for two reasons. Firstly, in spite of its large sunk costs, the purchasing of a boat was deemed more cost-effective in the long run. Moreover, the exclusive presence on board of MSF personnel - all equally committed to a humanitarian cause - was considered by MSF Barcelona's Head of Operations as conducive to greater cohesiveness and effectiveness.

By November 2015, when the weather conditions reduced the number of transits, all branches of MSF suspended SAR in the Central Mediterranean. MSF Brussels, however, continued operations in the Aegean in partnership with Greenpeace, relying on three rigid hulled inflatable rescue boats operated by Greenpeace and three ambulances stationing in the island of Lesbos. In the spring of 2016, the Bourbon Argos and Dignity I restarted operations offshore Libya upon invitation of the Italian Coast Guard. To date, MSF has reportedly assisted 20,129 people over 120 operations, conducting 80 disembarkations in Italian ports (MSF 2016).

\subsection{Sea-Watch}

As an international NGO with large financial resources and expertise, MSF can provide a sizeable contribution to maritime SAR. MOAS's experience, however, also provided an example to smaller, single-issue organisations with much more limited resources such as Sea-Watch.

Sea-Watch is a German-based NGO, stemming out of an ad hoc civil society initiative dedicated to securing maritime escape routes to Europe. It started operating in the Mediterranean after purchasing and refurbishing a 21-metre, 98-year-old Dutch trawler, renamed Sea-Watch 1, and manning it with eight personnel on board. Unlike MOAS and MSF, Sea-Watch refrains from taking migrants aboard and disembarking them in Italian ports. Its Central Mediterranean operations are based on the launching of a speedboat approaching migrant boats to provide life vests, drinking water, and urgent medical treatment. The Sea-Watch 1 crew then continue monitoring the situation until a bigger ship takes the migrants on board (Sea-Watch 2016).

Sea-Watch suspended operations in the Central Mediterranean in October 2015 in the face of worsening weather conditions. In November 2015, however, it started a new mission in the Aegean by means of a rigid inflatable boat stationing in the port of Lesbos. In April 2015, donations allowed Sea-Watch to replace its old boat with a newer 33 meters vessel capable of operating in all weather conditions, the Sea-Watch 2, now stationing close to the Libyan coasts. The operational model, based on not taking migrants on board, still remains the same for two reasons. Firstly, taking migrants on board would require disembarking them in a port in Sicily or even mainland Italy, which would entail withdrawing from the area of operations for a long time 
and large transportation costs. Secondly, Sea-Watch personnel maintain that SAR should remain a state responsibility. As all vessels with a certain capacity are obliged to take on people in distress, the space available inside the vessel was deliberately reduced in order to continue operating based on these tenets.

In spite of its small capabilities, Sea-Watch reportedly contributed to saving over 2,000 migrants. While Sea-Watch personnel admit that their material contribution to such a large emergency is only 'a drop in the ocean', their goals go beyond SAR in a narrow sense, as they also involved doing advocacy and finding imitators in civil society that could also conduct their own SAR operations (Sea-Watch 2015). Indeed, by showing that even a small civil society initiative with limited funding and expertise can provide a meaningful contribution to saving life at sea, Sea-Watch intends to shame European governments for their failure to act.

\subsection{See-Eye}

Nowhere is the process of emulation hoped for by Sea-Watch personnel more evident than in the recent involvement in SAR of newer NGOs such as See-Eye.

The newest NGO established for the search of migrants in distress, See-Eye was founded in the German city of Regensburg in the Autumn of 2015. Initial donations allowed for the purchasing and the reconversion of a 60 years old 23 meters former fishing cutter, which started operations offshore Sicily in May 2016 with 8 personnel on board (See-Eye 2016).

As admitted by its personnel, both the name and operational model of See-Eye closely resemble Sea-Watch's. Like Sea-Watch, see Eye conducts missions based on the spotting boats in distress and the provision of life vests, drinking water, and urgent medical treatment to those in need until the arrival of a larger boat that can take migrants aboard.

Unlike other organisations, Sea-Eye presently relies exclusively on volunteers, who partly cover their own travelling and living costs. While the operating costs are kept to a minimum, Sea-Eye estimates that 250,000 EUR will be needed to continue their operations until the Autumn of 2016. To date, donations collected through crowd funding only amount to around half of the amount needed. For this reason, Sea-Eye does not exclude the possibility to accept public funding in order to remain operational and extend the scope and professionalism of their activities.

\subsection{Pro-Activa}

The Sea-Watch model has also been adopted by Pro-Activa Open Arms.

Pro-Activa Open Arms is the charity established by Pro-Activa, a firm from Barcelona providing lifeguard and commercial diving on Spanish coasts. By relying on the firm's budget and personnel, Proactiva's founder Oscar Camps deployed the first NGO rescue team in the Aegean, relying on RHIBS and jet skis to conduct SAR offshore the island of Lesbos. By operating in the Aegean when the refugee crisis was attentively covered by international media, Pro-Activa Open Arms managed to collect around 500,000 EUR in donations from Spain and worldwide, which allowed for continuing its operations to the present day. The plummeting number of migrants crossing the Eastern Mediterranean, however, prompted Pro-Activa to relocate its activities to the Central Mediterranean since the beginning of June 2016, when it operates the 30 meters long sailing yacht Astral, received from a private donor and staffed with 10 Pro-Activa personnel with SAR and medical expertise. Due to the small size of the vessel presently available, Pro-Activa 
will refrain from boarding migrants unless strictly necessary, simply providing patrolling and humanitarian relief activities until migrants are embarked in a larger vessel.

While its operational model resembles Sea-Watch's, Pro-Activa is similar to MOAS as a philanthropic initiative created as a non-for-profit spin-off of a commercial enterprise providing services related to disaster management. Like MOAS, Pro-Activa Open Arms has relied on financial resources and expertise available within its sister, for-profit organisation, which may benefit from the commercial publicity obtained by saving migrants in distress.

\subsection{SOS Méditerranée}

While Sea-Eye and Pro-Activa have been using the SAR model first adopted by Sea-Watch as an operational template SOS Méditerranée (from now on 'SOS Med'), has deliberately mirrored MOAS's model, directly conducting fully-fledged SAR operations.

SOS Med was founded in May 2015, shortly after a series of disasters causing the death of 1,300 migrants. Its establishment occurred thanks to the initiative of the sea captain Klaus Vogel, who reportedly developed the idea of a SAR NGO after an encounter with a Senegalese stowaway. Vogel reached out to the French humanitarian Sophie Beau. Together, they created SOS Med as a network of three sister NGOs with headquarters in Germany, France, and Italy, collecting funding to start their own SAR operations. Vogel used his contacts in the maritime industry to charter a fishery protection vessel, the Aquarius. Larger than all vessels mentioned so far, the Aquarius is a 77-metre boat especially designed for SAR, can operate under all weather conditions, and is capable of hosting up to 200 migrants under deck and 500 in total. Thanks to its characteristics, the Aquarius is in an ideal position for operating in the open waters of the Central Mediterranean where it started operations on 26 February 2016. At the moment of writing, more than 1,200 migrants have been rescued and disembarked in Italian ports.

The Aquarius is staffed with 20 on-board personnel, including the German captain and sailors, a rescue team composed of five SOS Med personnel, and six medical personnel initially provided by the French NGO Médecins du Monde (MDM). Once MDM had to step down due to financial problems, it was replaced by MSF Amsterdam, which dispatched on the Aquarius two doctors, two paramedics, one interpreter, one cultural mediator, and one logistician. Rescues are conducted by means of two smaller inflatable boats shuttling from the migrants' vessels to the Aquarius. This operation is lengthy and may be problematic if migrants in distress are spotted too late. On 17 April 2016, the Aquarius approached a boats that was already partially sunk. While 108 people were saved, 28 were reported dead or missing (Cosentino 2016).

SOS Med running costs amount to EUR 11,000 per day. The total amount needed to conduct operations until the end of 2016 is 3.6 millions, one of which is still to be found. Like MOAS, SOS Med was initially funded primarily through crowd funding, largely consisting in relatively small private donations. The organisation also benefits from some small public funding, provided by the municipality of Paris. The memorandum of understanding recently signed with MSF Amsterdam commits MSF to cover a large part of the costs of SAR operations. In exchange, SOS Med accepted to refrain from accepting government funding, seen by MSF as incompatible with their commitment to neutrality and the willingness to distance themselves from European authorities.

Table 1: Non-governmental providers of SAR 


\begin{tabular}{|c|c|c|c|c|}
\hline Actor & Assets & Partnerships & Areas & Timing \\
\hline MOAS & $\begin{array}{l}40 \mathrm{mt} \text { Phoenix } \\
51 \mathrm{mt} \text { Responder } \\
2 \text { rescue boats }\end{array}$ & $\begin{array}{l}\text { Medical support by: } \\
\text { MSF Amsterdam in } 2014 \\
\text { Italian Red Cross and Emergency } \\
\text { in } 2016\end{array}$ & $\begin{array}{l}\text { Central } \\
\text { Med } \\
\text { Aegean } \\
\text { Andaman } \\
\text { Sea }\end{array}$ & $\begin{array}{l}\text { Aug '14 - } \\
\text { ongoing } \\
\text { October '15- } \\
\text { January '16 } \\
\text { January-March } \\
\text { '16 }\end{array}$ \\
\hline MSF & $\begin{array}{l}68 \mathrm{mt} \text { Bourbon } \\
\text { Argos } \\
50 \mathrm{mt} \text { Dignity } 1 \\
3 \text { rescue boats }\end{array}$ & $\begin{array}{l}\text { Own medical capabilities } \\
\text { RHIB pilots in the Aegean } \\
\text { provided by Greenpeace } \\
\text { Partnership between MSF } \\
\text { Amsterdam and SOS Med in } \\
\text { Central Med }\end{array}$ & $\begin{array}{l}\text { Central } \\
\text { Med } \\
\text { Aegean }\end{array}$ & $\begin{array}{l}\text { May '15- } \\
\text { ongoing } \\
\text { October '15- } \\
\text { January '16 }\end{array}$ \\
\hline $\begin{array}{l}\text { Sea- } \\
\text { Watch }\end{array}$ & $\begin{array}{l}21 \mathrm{mt} \text { Sea-Watch } 1 \\
33 \mathrm{mt} \text { Sea-Watch } 2 \\
1 \text { rescue boat }\end{array}$ & Own capabilities & $\begin{array}{l}\text { Central } \\
\text { Med } \\
\text { Aegean }\end{array}$ & $\begin{array}{l}\text { April '15- } \\
\text { ongoing }\end{array}$ \\
\hline $\begin{array}{l}\text { Sea- } \\
\text { Eye }\end{array}$ & $26 \mathrm{mt}$ Sea-Eye & Own capabilities & $\begin{array}{l}\text { Central } \\
\text { Med }\end{array}$ & $\begin{array}{l}\text { May '16 - } \\
\text { ongoing }\end{array}$ \\
\hline $\begin{array}{l}\text { Pro- } \\
\text { Activa }\end{array}$ & $\begin{array}{l}\text { RHIBS \& Jet Skis } \\
\text { in Aegean } \\
30 \mathrm{mt} \mathrm{Astral} \mathrm{in} \\
\text { central Med }\end{array}$ & Own capabilities & $\begin{array}{l}\text { Aegean } \\
\text { Central } \\
\text { Med }\end{array}$ & $\begin{array}{l}\text { September '15- } \\
\text { April 2016 } \\
\begin{array}{l}\text { June } \\
\text { ongoing }\end{array}\end{array}$ \\
\hline $\begin{array}{l}\text { SOS- } \\
\text { Med }\end{array}$ & $77 \mathrm{mt}$ Aquarius & $\begin{array}{l}\text { Medical and financial support from } \\
\text { MSF Amsterdam }\end{array}$ & $\begin{array}{l}\text { Central } \\
\text { Med }\end{array}$ & Feb '16-ongoing \\
\hline
\end{tabular}

\section{The proliferation of Search and Rescue NGOs}

Since the spring of 2015, six different NGOs have taken up the challenge of complementing state efforts by deploying their own SAR capabilities. In the Central Mediterranean and the Aegean alike, these organisations have provided a crucial contribution to mitigating the loss of life at sea. This section outlines the five key factors underlying the rapid proliferation of SAR NGOs.

The first, most obvious enabler of non-governmental SAR lies in the visibility of the migration crisis. The humanitarian emergency in the Mediterranean had a strong impact on European civil society, creating the impetus for action, increasing the perceived legitimacy of SAR NGOs 
before local authorities and their ability to secure funds. Secondly, the non-governmental provision of SAR has been enabled by the changing regulatory and normative environment. Most notably, Italian government's commitment to allow for disembarkation in its ports have ensured the possibility to conduct rescues without substantial risks of legal prosecution. Besides being lawful, maritime SAR is also eminently feasible. Conducting maritime SAR is relatively cheap, posing limited challenges and risks for humanitarian personnel. Relatedly, the low costs of maritime SAR, combined with the ability to secure funding via small internet donations, have made the performing of maritime SAR financially viable even for small, newly established charities. Lastly, the presence of a tight information network between NGOs, which have explicitly encouraged other organisations to join, further reduced the costs and hurdles of the non-governmental provision of SAR, allowing for a process of emulation to take place.

\subsection{Visibility}

While coverage of the migration crisis varies across European newspapers, the latest tragedies in the Mediterranean have achieved high media salience (European Journalism Observatory 2015, Berry, et al. 2015). The iconic images of drowned migrants, such as the 3 years old Syrian Aylan Kurdi washed ashore in Samos, forcefully epitomised states' failure to respond to the humanitarian emergency, repeatedly denounced by moral authorities such as Pope Francis. The founders of both MOAS and SOS-Mediterranee decided to start operations after directly witnessing migrants' suffering. MSF saw maritime SAR as a natural extension of the migrants' humanitarian relief activities they were carrying out ashore. Newer organisations, such as SeaWatch, Sea-Eye and Pro-Activa, however, report they were directly compelled to act by media reports of the ongoing crisis.

The ample media coverage of the migration crisis did not only directly encourage the proliferation of SAR NGOs, but also strengthened the legitimacy of their activities, covered at length by local and international media. For instance, SOS-Mediterranee hosted a BBC crew aboard of the Aquarius, while Sea-Watch had different crews of both national and regional German televisions aboard. SAR NGOs were depicted in a very positive light, and often referred to as philanthropists, (BBC 2014), or even 'the angels of the Mediterranean' (Cosentino 2016). Far from being merely the target of media broadcasting, NGOs themselves have proactively attempted to shape the public debate. MOAS' founders, for instance, have been interviewed by and written op-ed for international media such as Time, BBC, and $\mathrm{CNN}$, and recently organised a widely publicized public debate involving media and activists from around the world. SeaWatch, by contrast, explicitly sought to replicate the public outrage raised by the photos of Aylan Kurdi by releasing pictures of a drowned baby encountered in one of their operations, labelled as the 'new symbol of the migrant crisis' (CNN 2016).

The enduring salience of the migration crisis, the ample coverage of SAR NGOs and the ability of these organisations to effectively advertise their activities have generated substantial support from civil society worldwide. This has ensured the availability of a large pool of volunteers willing to work for these organisations. Even more importantly, the combination of media coverage and new funding opportunities such as internet crowd funding has ensured the financial 
viability of their operations. Research shows that European media and public opinion approach towards the migrations crisis changed substantially after the publication of dramatic images such as the drowned body of Aylan Kurdi (European Journalism Observatory 2015). This had large implications on SAR NGO fundraising. In the day the pictures were published, donations for MOAS increased fifteenfold, jumping from 10,000 to 150,000 EUR (Elgot 2015). Other organisations also note a strong connection between media coverage and the amount and provenance on donations. Pro-Activa, for instance, reported a large increase in donations received from the US after its SAR operations in Lesbos were first covered by the CNN.

\subsection{Legitimacy}

The duty to aid people in danger of drowning - sometimes referred to as the unwritten law of the sea - is a longstanding international norm. Long enshrined into customary international law, the duty to aid people in distress at sea has been codified in several international conventions. Under Article 98 of the United Nations Convention on the Law of the Sea (UNCLOS) -which reinstates the obligations already enshrined by the 1974 Convention for the Safety of Life at Sea and the 1978 Search and Rescue Convention - flag states and coastal states have a duty to render assistance to those in distress in the sea areas identified as their one (UNHCR 2016, Mann 2016, Trevisanut 2013, 2010).

While clearly stated in international treaties and customary law, the duty to assist people in distress at sea has been inhibited by domestic legislation criminalising illegal migrations and the facilitation thereof. Italian law, for instance, considers abetting illegal immigration as a criminal sanction punishable with up to 3 years in jail and a fine of 15,000 EUR per clandestine migrant (Cuttitta 2014). European legislation too requires member states to punish ' any person who intentionally assists a person who is not a national of the member states to enter the territory of a Member State', but concedes that states 'may decide not to impose sanctions ... where the aim... is to provide humanitarian assistance' (Human Rights at Sea 2016).

The risks arising from these conflicting legal obligations are apparent in the history of Cap Anamur. As mentioned in section two, this German NGO provided SAR in South East Asia starting from 1979, and more recently operated in the Central Mediterranean too, where in in June 2004 it came across a deflated rubber dingy with 37 people aboard (Cuttitta 2014: 22-3). The Cap Anamur took the migrants on, but Italy, Germany, and Malta alike denied the authorisation to disembark them (Cuttitta 2014: 22-3, Coppens and Somens 2010). After a long period of waiting, the vessel landed without authorization in the port of Agrigento. The shipmaster, first officer, and head of the humanitarian organisation were then prosecuted under the charge of aiding and abetting illegal immigration. While Cap Anamur's personnel were subsequently acquitted, their prosecution had legal, financial and emotional repercussion, leading to the closing of the NGO. The Cap Anamur case was a warning not only against NGOs, but also other private vessel owners, ultimately inhibiting them from abiding by SAR duties (Cuttitta 2014: 22-3; Basaran 2015: 211). 
Eventually, however, the legal environment has changed, making the possibility for prosecution far more unlikely. Italy has committed to always permitting the disembarkation in Italian ports of all migrants rescued in the Maltese and Libyan SAR zones too. Moreover, Italian authorities have embraced a very broad interpretation of the notion of 'boat in distress', considering all overloaded migrant vessels at risk of capsizing and therefore in immediate danger. Furthermore, while the offence of abetting illegal immigration remains present, the eventual acquittal of the Cap Anamur crew and the declining fortunes of parties demanding a tougher stance on illegal immigrations such as the Northern League - no longer a government coalition partner since 2011 - have created additional space for non-governmental SAR. The changing approach of the Italian government is especially evident in their stance towards non-governmental SAR personnel, repeatedly praised by Italian authorities and invited to cooperate with Italian Coast Guard and Navy and attend institutional meetings. Most notably, the Italian President Mattarella awarded MOAS' founder Regina Catrambone a medal for her outstanding contribution 'to assisting migrants in distress' (Quirinale 2015).

The Greek government, by contrast, showed a tougher stance by making the patrolling of Greek territorial waters illegal, and repeatedly threatened prosecution against proactive SAR operations. In March 2016, three NGO personnel were arrested with the charge of abetting illegal migrations, but were subsequently released without any trial. Even in Greece, however, the risk of prosecution is seen as unlikely for three reasons. Firstly, the EU facilitation directive and Greek legislation alike clearly waive humanitarian personnel conducting SAR from any legal sanctioning. Moreover, NGOs can find external expertise helping them to navigate the legal complexities of SAR. The non-profit organisation Human Rights at Sea (2016), for instance, provides SAR NGOS with specific guidance on how to avoid criminalisation. Lastly, NGO operatives and Greek Coast Guard spokespersons alike consider the risk of prosecution remote due to the reputational damage this would impose on the Greek government.

As stressed by all interviewees, the awareness that rescue and disembarkation activities could be performed lawfully and the willingness of local authorities to accept NGOs as legitimate providers of SAR have been crucial preconditions for their activities to take place. As a precautionary measure to make the risk of prosecution further unlikely, all NGOs also established additional measures, such as liaising with legal scholars, hiring legal advisors and conducting SAR operations only in coordination with and under the authorization of local Coast Guards.

\subsection{Feasibility}

Not only is the conduct of SAR operations lawful and widely perceived as legitimate and praiseworthy. Mediterranean SAR operations are also practically feasible at relatively contained costs.

To be sure, conducting maritime rescues require different types of expertise, ranging from sailing to medical and emergency rescue training. It is no coincidence that some of the NGOs - such as 
MOAS and Pro-Activa - originated from business organisations with expertise on how to operate in crisis environments or conduct lifeguard services. As bluntly stated by MOAS' founder, 'I rescue people for money in my other job. I know what to do' (Tremlett 2015). MOAS' reliance on former Maltese Coast Guard and military personnel further indicates their commitment to conducting professional SAR.

While important, however, professional expertise in the field of disaster management is not strictly essential, and other SAR NGOs have employed volunteers with disparate backgrounds. The only indispensable skills required to conduct SAR - namely the ability to operate small vessels and provide emergency medical care - can be easily found within civil society. Even when maritime expertise is not directly available within an organisation, it can be achieved by chartering both a vessel and its crew, as done by MSF Brussels with the Bourbon Argos. Moreover, missing know-how can be found by means of inter-organisational partnerships. The deals between SOS Mediterranee and MSF Amsterdam for the provision of medical personnel or MSF Brussels and Greenpeace for operating RHIBS in the Aegean are a case in point.

Nor is the acquisition of all necessary assets an insurmountable problem. In the Aegean, the possibility to only use RHIBs directly departing from Greek ports -without any need for larger ships permanently stationing at sea - further reduced the hurdles and costs associated with SAR. Even in the Central Mediterranean, the possibility to charter or directly purchase and reconvert old and relatively cheap fishing boats such as the Phoenix, Sea-Watch 1 and Dignity I, has allowed NGOs to start operations in a swift and relatively inexpensive fashion. The SAR model developed by Sea-Watch, Sea-Eye and Pro-Activa - based on not taking migrants on board poses especially few challenges, further reducing the personnel and transportation costs associated with operating large vessels and disembarking migrants in Italian ports.

Furthermore, humanitarian relief activities in environments plagued by conflict and social unrest require knowledge of the local territory and the presence of security officers or even armed escorts (Stoddard at al. 2008). The provision of maritime SAR, by contrast, poses limited challenges to the safety of humanitarian personnel. To be sure, maritime SAR is not completely exempt from danger. Recently, an unidentified vessel whose crew claimed to be Libyan Coast Guards fired warning shots against the Sea-Watch 2 and attempted to seize it violating Libyan sovereignty. Other risks have been raised, ranging from the possibility that Islamic State militias operating in the coastal area of Sirte may attempt to kidnap humanitarian personnel or use floating improvised explosive devices against SAR boats to the risk of riots among migrants fearing forced repatriation. These risks, however, are minor in comparison to the danger faced by humanitarian NGOs conducting their activities in conflict areas.

The relative practicability and safety of maritime migrant rescuing in the Mediterranean are therefore another key catalyst of the non-governmental provision of SAR. Far from denying the feasibility of conducting these operations, personnel from Sea-Watch and Sea-Eye deliberately stress that maritime SAR can be conducted without major difficulties. Indeed, the very rationale underlying their creation is the willingness to illustrate that even small, volunteer-based 
organisations can easily save lives at sea, thereby shaming public authorities and showing that the failure to rescue migrants is only caused by lack of political will.

\subsection{Financial viability}

The combination of media visibility, practical feasibility and novel forms of fundraising have ensured the financial viability of maritime SAR activities. Crowd funding, usually referred to as distributed small-scale fundraising often facilitated by technology, first proved its potential in sustaining humanitarian action in the wake of the earthquake in Nepal, when small internet donation helped sustained the activities of local NGOs Different forms of crowd funding exist. Non-governmental organisations have usually relied primarily on the donation-based model, consisting in the giving of small amounts of money for charity purposes (OCHA 2015) .

Donation-based internet crowd funding has been by far the most important source of funding for SAR NGOs. With the exception of a much larger organisation like MSF, all other SAR NGOs have relied almost exclusively on crowd funding, reporting that most of their wherewithal comes from small internet donations. Pro-Activa, for instance, collected around 500,000 EUR by means of 7,000 donations, with an average of about 70 EUR per donation. While not absent, larger donations from private foundations and other charities only account for a relatively small share of SAR NGOs funding.

To be sure, such fundraising strategies entail some risks. Resources collected through crowd funding tend to be not only small in scale, but also erratic and unreliable, and are therefore deemed insufficient for large-scale humanitarian projects (OCHA 2015). To date, the visibility of SAR NGOs and the ability to keep the costs down have ensured the viability of their internet crowd funding-based financial model. Small SAR NGOS, however - whose small budget is almost entirely absorbed by their running costs - acknowledge the risk that funding could dry up, causing the sudden interruption of their activities. For this reason, some organisations have speculated about the possibility of accepting and proactively seeking funding from governments and the EU. MOAS' funder, for instance, recently called for 'the generous support of public donors to keep saving lives' (MOAS 2016b). The acceptance of public funding for maritime SAR, however, is criticized by other organisations as a practice that could compromise NGOs' neutrality and ultimately pave the way to an 'outsourcing of state responsibilities'. MSF has been especially vocal in warning against accepting funds from the very public institutions held responsible for the migrations crisis. For this reason, the Memorandum of Understanding between SOS Mediterranee and MSF Amsterdam, commits SOS Med to refrain from accepting public funding in order for its collaboration with MSF to continue.

\subsection{Emulation}

A latest catalyst of the proliferation of non-governmental providers or SAR is the existence of an ongoing process of emulation. As shown in the previous section, newer SAR NGOs have deliberately adopted the templates established by their predecessors, who willingly shared their experience and operational practices. Institutionalist theory has consistently identified emulation 
as one of the logics underlying the tendency for both public and private organisations to develop similar structures and procedures (Di Maggio and Powell 1983), arguing that institutional entrepreneurs seek to imitate existing models seen as attractive solutions to the problems they face (Beckert 2010:156). Emulation is a process that has already been documented by the scholarship on NGOs operating in the most disparate sectors (Yasuda 2015; Hamanack and Heydemann 2009).

The tendency to adopt existing organisational templates is especially pronounced in a domain such as the non-governmental provision of maritime rescues for at least two reasons. SAR NGOs are mostly small, newly established organisations with few resources and in house expertise. Even a large organisation such as MSF had no previous expertise on maritime SAR, which posed a completely novel challenge. The novelty of the problems faced, the need to start operations quickly, and the small size of most SAR organisations all created strong incentives for adopting solutions already been proven effective by others, thereby reducing learning costs and circumventing uncertainty. Due to these reasons, it was natural for all SAR NGOs to look at the model provided by MOAS, which had already proved capable of conducting SAR operations effectively in close coordination with the Italian Coast Guard. To be sure, however, the MOAS model was not adopted blindly. As the latest scholarship on emulation suggests, different financial resources, operational capabilities and normative frames explain why organisations' process of adaptation is often conducive to different organisational structures and solutions (Beckert 2010). As mentioned in the previous section, two distinct non-governmental SAR models can be found: the MOAS model and the Sea-Watch model.

Organisations following the MOAS model, namely the Brussels and Barcelona branches of MSF and SoS-Med, have conducted fully-fledged SAR operations by chartering larger vessels capable of directly taking migrants on board and disembarking them in the port indicated by Italian authorities. MSF and SOS-Med, however, did not adopt the MOAS model uncritically. Some of the solutions devised by MOAS, namely the hiring of former military personnel and the usage of drones, were explicitly discarded as inappropriate for an NGO. At the same time, however, both MSF and SOS Med personnel have openly credited MOAS for providing them with a template that could be adopted by other organisations, thanking them for sharing their experience and know-how to newcomers. One spokesperson from SoS-Med explicitly defined his organisation as the outcome of a 'healthy process of emulation'.

While looking at the activities of MOAS as an example, smaller organisations such as SeaWatch, See-Eye and Pro-Activa have decided to develop a different type of operations based on not taking migrants on board. Two factors account for the development of this alternative model. The first is resource constraints. As smaller organisations, Sea-Watch, Sea-Eye, and Pro-Activa did not have the wherewithal to acquire large boats, man them with sufficient personnel, and face the large costs in diesel arising from the obligation to disembark migrants in the port indicated by Italian authorities, sometimes located far away in mainland Italy or Sardinia. Resource constraints, however, are not the sole factor accounting for this decision, which is also explained by different normative frames. Specifically, Sea-Watch founders consider taking migrants on board as a duty to be carried out by governments, fearing that having NGOs conduct such 
activities could cause states to abdicate their responsibility and provide a justification for their inaction. For this reason, Sea-Watch has developed an alternative model that seeks to mitigate the loss of life at sea by providing support to migrants in distress while asking for the sending of Coast Guard or military assets to transfer migrants on board. This explains why Sea-Watch did not change their model even after they acquired a bigger vessel and larger financial resources.

By reducing learning costs and helping to cope with the uncertainty of a novel activity, emulation therefore enabled the rapid proliferation of non-governmental SAR providers.

\section{Conclusions: the effectiveness of SAR NGOs}

Within less than three years, six different non-governmental NGOs have taken up the challenge of countering the loss of life in the Mediterranean. Other organisations have expressed their interest in engaging in SAR and may soon follow. The Berlin youth association Jugend Rettet, for instance, has already collected 300,000 EUR, reconverted a former fishing vessel capable of hosting up to 100 people onboard and deployed it to Malta. But how effective are NGOs in mitigating the loss of life at sea? This concluding section briefly addresses this crucial question before summarising the findings of the article and outlining some avenues for future research.

The Central Mediterranean corridor is a very important sea lane for commercial shipping. Besides being patrolled by Italian, Maltese and international military and Coast Guard assets, the Central Mediterranean is therefore frequently crossed by ferries, oil tankers, containers and cruise ships alike. Based on the legal duty to assist people in distress, all these vessels are obliged to conduct SAR. The Italian Maritime Rescue Coordination Centre (MRCC) in Rome, which keeps track of the position of all vessels transiting in the area, can require any of the closest ship to conduct SAR operations if a migrant boat is nearby.

Given the large amount of ships in the area, one may consider the contribution of eight NGO vessels negligible. As emphasised by Italian Coast Guard officers, however, none of the assets presently deployed in the Mediterranean but NGOs' have SAR as their primary mission. Triton, as often emphasized, only operates within 30 miles away from the Italian coast, and has proven tragically ill-equipped for SAR. EUNAVFOR Med and Mare Sicuro mandates revolves around countering smuggling and other illegal activities. Commercial shippers have financial disincentives to conduct SAR, and are even reported to deliberately avoid migrants' transit areas in order not to be asked to conduct a rescue (Aarstad 2015). Moreover, none of the abovementioned assets are ideal to conduct SAR. Large military and commercial boats alike usually have a high deck that complicates the embarkation of migrants on board, and sometimes lack the manoeuvrability to approach small boats which can very easily capsize. Even the Italian Coast Guard, which has both coordinated and directly conducted a very large amount of SAR operations, is a military organisation whose main duty consists in policing Italian coasts, and whose capacity to save migrants in the Southern Mediterranean is reduced by the need to preserve its readiness for unexpected contingencies on national waters. 
Hence, while the capabilities of NGOs are relatively small, the fact that their assets are exclusively dedicated to SAR makes their contribution to rescuing migrants invaluable. NGOs' contribution to mitigating the loss of life at sea is threefold. Firstly, SAR NGOs have directly saved at least 25,000 migrants. Moreover, by covering certain areas of the large sea region between Sicily and Libya, they have released other Coast Guard and military assets to conduct SAR missions in other zones, thereby acting as force multipliers. Lastly, thanks to their advocacy and media presence, SAR NGOs have raised further awareness of the humanitarian emergency in the Mediterranean before public opinion, thereby pressuring governments to act more proactively to mitigate the loss of life at sea.

The importance and moral praiseworthiness of SAR NGOs is therefore unquestionable. To be sure, however, non-governmental SAR also suffers limitations. Specifically, the ability of NGOs to operate is conditional upon the Italian government's willingness to allow for the disembarkation of migrants in Italian ports. As SAR operations require disembarkation in the nearest place of safety, the willingness of at least one nearby coastal state to authorize disembarkation in its territory is a sine qua non for NGO rescue missions to take place. Such a willingness to open ports to those rescued at sea - which is absent in many other coastal states worldwide - should not be taken for granted. Moreover, non-governmental rescue operations may have unintended consequences. SAR missions like Mare Nostrum have been criticized as a 'pull factor' of migrations. As forcefully illustrated by the increase in migrant crossings after Mare Nostrum was cancelled, no correlation exists between the presence of SAR assets at sea and the volume of migratory flows (Toaldo 2015). However, the presence of SAR operations close to Libyan coasts may facilitate smuggling, encouraging the use of increasingly overloaded and unseaworthy boats.

This exploratory article has provided the first systematic contribution to the study of nongovernmental SAR in the Mediterranean by conducting a comparative analysis of each of these organisations and analysing the reasons underlying their proliferation. More research is needed to investigate this newly established maritime humanitarian space, map the coordination with state authorities and comparatively assess the effectiveness of both state and non-governmental SAR models. 


\section{References}

Aarstad, Åsne Kalland (2015). 'The Duty to Assist and Its Disincentives: The Shipping Industry and the Mediterranean Migration Crisis', Mediterranean Politics, 20/3: 413-9.

Amnisty International, 'A safer sea. The impact of increased search and rescue operations in the Central Mediterranean (July 2015).

Basaran, Tugba (2015), 'The Saved and the Drowned: Governing Indifference in the Name of Security', Security Dialogue, 46/3: 205-20.

Beckert, Jens (2010). 'Institutional Isomorphism Revisited: Convergence and Divergence in Institutional Change', Sociological Theory, 28/2: 150-66

Berry, Mike, Garcia-Blanco Inaki, and Moore, Kerry, 'Press Coverage of the Refugee and Migrant Crisis in the EU: A Content Analysis of Five European Countries', Report prepared for the United Nations High Commission for Refugees', December, http://www.unhcr.org/56bb369c9.pdf

Carrera, Sergio, and Den Hartog, Leonhard (2015), 'Whose Mare? Rule of Law Challenges in the Field of European Border Surveillance in the Mediterranean, Brussels, CEPS Paper 79, January, https://www.ceps.eu/system/files/LSE 79.pdf

Catrambone, Christopher (2016). 'What I've Learned Rescuing Migrants in the Mediterranean', Time, 29 January.

CNN, 'Heartbreaking Photo New Symbol of Growing Crisis', 1 June, http://edition.cnn.com/videos/world/2016/06/01/migrant-deaths-in-mediterranean-sea-sesayintv.cnn/video/playlists/atv-cnn-in-depth/

Coppens, Jasmine, and Somers, Eduard, 'Towards New Rules on Disembarkation of

Persons Rescued at Sea?', The International Journal of Marine and Coastal Law 25 (2010) 377403

Cosentino, Raffaella, 'In Mare con gli Angeli del Mediterraneo', Repubblica, 2 June. http://inchieste.repubblica.it/it/repubblica/rep-

it/2016/06/02/news/il_soccorso_in mare dei profughi-140950243/

Council of the European Union (2016), 'Timeline - response to the migrations crisis', http://www.consilium.europa.eu/en/policies/migratory-pressures/history-migratory-pressures/

Council of the European Union (2016b). 'Refugee facility for Turkey: Member States Agree on Details of Financing', Brussels, 3 March. 
Chryssogelos, Angelos (2016). 'NATO New Mission in the Aegean is a Victory for Turkey and a Proof of Europe's Strategic Irrelevance, LSE Europblog, http://blogs.lse.ac.uk/europpblog/2016/02/24/natos-new-migrant-mission-in-the-aegean-is-avictory-for-turkey-and-proof-of-europes-strategic-irrelevance/

Cuttitta, Paolo (2014). 'From the Cap Anamur to Mare Nostrum: Humanitarianism and Migration Controls at the EU's Maritime Borders', CLEER Working Paper 7, 21-37.

Elgot, Jessica (2015). 'Charity behind Migrant Rescue Boat Sees 15-Fold Rise in Donations in 24 Hours', The Guardian, 34 September 2015. http://www.theguardian.com/world/2015/sep/03/charity-behind-migrant-rescue-boats-sees-15fold-rise-in-donations-in-24-hours

European Parliament Directorate-General for External Policies, 'Migrants in the Mediterranean: Protecting Human Rights', http:/www.europarl.europa.eu/RegData/etudes/STUD/2015/535005/EXPO STU(2015)535005 EN.pdf

DiMaggio, Paul J., and Walter W. Powell. 1983. 'The iron cage revisited: Institutional isomorphism and collective rationality in organizational fields', American Sociological Review 48:147-60.

European Journalism Observatory (2015), ‘ Research: How Europe’s Newspapers Reported The Migration Crisis', 9 November, http://en.ejo.ch/research/research-how-europes-newspapersreported-the-migration-crisis

Renée C. Fox (2014), Doctors Without Borders: Humanitarian Quests, Impossible Dreams of Medicins Sans Frontieres, Baltimore: Johns Hopkins UP

Flynn, Michael and Cannon, Cecilia (2009), 'The Privatization of Immigration Detention: Towards a Global View', Global Detention Project Working Paper, http://www.globaldetentionproject.org/fileadmin/docs/GDP_PrivatizationPaper_Final5.pdf

George, Alexander L. and Andrew Bennett. 2005. Case Studies and Theory Development in the Social Sciences. Cambridge: MIT Press.

Hamanack, David, and Heydemann Steven (eds) (2009). Globalization, Philanthropy, and Civil Society, Bloomington: University of Indiana Press.

Heller, Charles, Pezzani, Lorenzo et al (2016), 'Death by Rescue', Forensic Architecture Agency, https://deathbyrescue.org/report/narrative/

Human Rights at Sea, 'Volunteer Maritime Rescuers: Awareness of Criminalisation', Southampton, April 2016.

International Organisation for Migrations (2016). 'Missing Migrants Project', 


\section{http://missingmigrants.iom.int/}

Kingsley, Patrick and Ian Traynor (2015). 'EU borders chief says saving migrants' lives "shouldn't be priority" for patrols', The Guardian, 22 April 2015. http://www.theguardian.com/world/2015/apr/22/eu-borders-chief-says-saving-migrants-livescannot-be-priority-for-patrols

Llewellyn, Sabine (2015). 'Search and Rescue in Central Mediterranean Sea', Migreurop, 20 August, http://www.migreurop.org/IMG/pdf/report_wtm_migreurop-arci-ep_08242015.pdf

Mann, Itamar (forthcoming 2016), Humanity at Sea, Maritime Migration and the Foundations of International Law (Cambridge: Cambridge CUP).

Médecins Sans Frontières (2016). "Refugee Crisis: MSF Ends Search and Rescue Operations in the Mediterranean", MSF UK, 5 January, http://www.msf.org.uk/article/refugee-crisis-msf-endssearch-and-rescue-operations-in-the-mediterranean

Ministero della Difesa (2015) 'Visita del Ministro alle navi del dispositivo Mare Sicuro', Comunicato Stampa 102, 23 December.

MOAS (2016a), 'MOAS Launches Pioneering South East Asian Mission to Track Movement of Refugees at Sea', 26 February.

MOAS (2016b), 'MOAS launch 2016 Mediterranean mission with two ships, two drones patrolling the "dead zone", 31 May.

UN for the Coordination of Humanitarian Affairs (OCHA) (2015), 'Crowdfunding for Emergencies, OCHA Policy and Study Series 016, https://docs.unocha.org/sites/dms/Documents/OCHA_TB16_Crowdfunding_for_Emergencies_o nline.pdf

Patalano, Alessio (2015), 'Nightmare Nostrum? Not Quite', RUSI Journal, 160/3: 14-19.

Perkowsky, Nina (2016), 'Deaths, Interventions, Humanitarianism and Human Rights in the Mediterranean "Migration Crisis", Mediterranean Politics 21/2, 331-335.

Pollack, Sorcha (2016), 'LÉ Róisín rescues 395 migrants in the Mediterranean’ Irish Times, 23 May.

Quirinale (2015), 'Il Presidente Mattarella ha consegnato motu propio 18 onoreficenze OMRI', 10 October, http://www.quirinale.it/elementi/Continua.aspx?tipo=Comunicato\&key=959

Scammell, Rosie (2016), 'How 150,000 people were saved in the Mediterranean', IRIN: Humanitarian News and Analysis, 7 January. http://www.irinnews.org/report/102337/how-150000-people-were-saved-in-the-mediterranean 
MOAS (2015), 'MOAS Drones to Keep Flying Thanks to Generous Schiebel Donation', https://www.moas.eu/moas-drones-to-keep-flying-thanks-to-generous-schiebel-donation/

Sea-Eye (2016), 'Il Progetto', Sea-Eye.org, http://sea-eye.org/it/die-seerettung/

Sea-Watch (2016), 'General information', Sea-watch.org, http://sea-watch.org/en/

Schiebel Press (2014), 'Schiebel CAMCOPTER helped to save more than 2800 Migrants', 31 October.

Stoddard, Abby, Adele Harmer and Victoria DiDomenico (2008). 'The Use of Private Security Providers and Services in Humanitarian Operations', Humanitarian Policy Group Report, 27 October.

Tardy, Thierry (2015), 'Operation Sophia. Tackling the Refugee Crisis with Military Means', EU Institute for Security Studies Brief 30.

Toaldo, Mattia (2015), 'Libya's Migrant Smuggling Highway: Lessons for Europe', European Council for Foreign Relations Policy Memo, November 2015.

Travis, Alan (2014), 'UK Axes Support for Mediterranean Migrant Rescue Operation', Guardian, 27 October 2014. http:/www.theguardian.com/politics/2014/oct/27/ukmediterranean-migrant-rescue-plan

Tremlett, Travis (2015), 'The millionaire who rescues migrants at sea', Guardian, 8 July. http://www.theguardian.com/news/2015/jul/08/millionaire-who-rescues-migrants-at-sea

Trevisanut, Seline (2013), 'Law of the Sea Symposium: Search and Rescue Operations at SeaWho is in Charge? Who is Responsible?', Opinio Juris, 28 May, http://opiniojuris.org/2013/05/28/law-of-the-sea-symposium-search-and-rescue-operations-atsea-who-is-in-charge-who-is-responsible/

Trevisanut, Seline (2010), 'Search and Rescue Operations in the Mediterranean: Factor of Cooperation or Conflict?', International Journal of Marine and Coastal Law, 25: 523-40.

UN Refugee Agency, International Institute of Humanitarian Law, and International Organisation for Migrations (2016), 'Workshop on Search and rescue of refugees and migrants in the Mediterranean: Practitioners' Perspectives' Sanremo, 7-9 March, http://www.iihl.org/wpcontent/uploads/2016/05/IIHL-SAR-workshop-report-_March-2016.pdf

Yasuda Yumiko (2015), Rules, Norms and NGO Advocacy Strategies, London: Routledge.

Zandonini, Giacomo (2016), 'Migranti, riprende la rotta egiziana ma senza siriani', Repubblica, 15 May, http://www.repubblica.it/solidarieta/immigrazione/2016/05/15/news/migranti$139844192 /$ 